\title{
A Book Review
}

Salah Stétié. Fils de la parole: Un poète d'Islam en Occident. Interview with Gwendoline Jarczyk. Paris. (Albin Michel). 2004. 263 pages. C19.50. ISBN 2-226-15192-3

\author{
Jamal En-nehas
}

alah Stétié's Fils de la parole: Un poète d'Islam en Occident (Son of the Word: A Poet of Islam in the West) is a transcription of Gwendoline Jarczyk's interview with the author on several topics ranging from the professional and academic to the personal. Stétié uses his position as a self-exiled Arab writer in the West and draws on his lifelong experience in journalism, teaching, and diplomacy to comment on the relationship between the East and the West and on his role as cultural mediator. While admitting to the divisive nature and the devastating role of the seemingly endless crises which mark our epoch, Fils de la parole promotes a perspective which is diametrically opposed to the apocalyptic Huntingtonian imperative of conflict and collision, commonly referred to as the clash of cultures and civilizations. To reinforce his "alternative" idea of entente and rapprochement between the East and the West, Stétié delves into their common histories. He particularly refers to the Mediterranean region as a cross-fertilizer, a perennial locus classicus of cultural encounters and exchanges. He talks laudably about the accomplishments of the Mediterranean civilizations over the centuries, emphasizing that a major portion of human history has been produced in this relatively small area. Stétié presents himself as the product of this hybridizing process, the "tissage" (in lieu of Léopold Sédar Senghor's ?métissage") of cultures and influences. He is an Arab who has developed a fondness for what he terms "francophonie" or "francité," clichés which reflect a dual culture wherein Eastern and Western values are smoothly reconciled.

Born in Lebanon, Stétié emigrated to France, where he quickly adjusted to the tempo of French life and came under the spell of the French literary tradition. Nonetheless, he admits that his medium of expression is almost exclusively Western, that is to say French, which inevitably provokes a series of intimations about rupture and identity politics, expressed in various parts of the book in diffusive yet less poignant terms. Stétié's valorization of the poetics to the detriment of the politics of the issues his interlocutor raises with him compromises much of what readers would deem the heart of the matter, i.e. the interplay of language, culture, and politics.

When Stétié seriously talks about politics, it is clearly to denounce modern society's failure of imagination and lack of wisdom, and how these can lead to war, violence, and affliction, as exemplified by the American invasion and occupation of Iraq. Stétié argues that, of all forms of hegemony, the British has been the most devastating. All the woes of contemporary societies are the corollaries of the injustices inflicted upon the subjects of the empire, and the current stalemate in Middle Eastern politics is the natural result of the empire and the injudicious stratagems of its masterminds. Stétié, however, does not comment fully enough on his political statements, nor does 
he put forward any foreseeable remedies.

The impromptu nature of the interview, and the author's desire to be all-inclusive, make the book appear somewhat disjointed, as both interviewer and interviewee deliberately ramble and do not appear constrained by any discursive engagement or thematic consistency. In the absence of a clear pronouncement on the background of the interview, one can only assume that spontaneity is used simply in order to justify the rambling, which can also be ascribed to the disparate and complex topics Stétié is invited to comment on.

Owing to the complex and heterogeneous nature of the topics raised in Fils de la parole, it would be unfair to claim that the task of addressing them satisfactorily is an easy one. Consequently, Stétié often finds himself conve- niently bracketing some vital information and resorting to ellipses in a desperate attempt to bring about some form of closure. This is likely to be viewed either as a discursive strategy, which simply implies that closure is anything but possible, or as a mere penchant for obscurantism. The reader might be tempted to opt for the latter, which finds reverberations in several parts of the interview wherein Stétié openly admits to the role mysticism and ambiguity play in his personal life. "I am a man of ambiguity," he says. This is also clear in his use of puns as he constantly struggles to define concepts and situations. On the other hand, one might infer that Stétié finds in ambiguity and mysticism the means to portray the sense of fragmentation and uncertainty which characterizes the modern world. 